\title{
Is creatine kinase associated with outcome in COVID-19?
}

\author{
Daniele Orsucci \\ Unit of Neurology, San Luca Hospital, Via Lippi-Francesconi, Lucca 55100, Italy. \\ Correspondence to: Dr. Daniele Orsucci, Unit of Neurology, San Luca Hospital, Via Lippi-Francesconi, Lucca 55100, Italy. \\ E-mail: orsuccid@gmail.com
}

How to cite this article: Orsucci D. Is creatine kinase associated with outcome in COVID-19? Neuroimmuno/ Neuroinflammation 2021;8:216-21. http://dx.doi.org/10.20517/2347-8659.2020.53

Received: 10 Aug 2020 Accepted: 25 Aug 2020 Available online: 21 Sep 2021

Academic Editor: Athanassios P. Kyritsis Copy Editor: Cai-Hong Wang Production Editor: Jing Yu

The new "severe acute respiratory syndrome" (SARS)-correlated coronavirus (SARS-CoV-2), first isolated from three patients from Wuhan (China), has been spreading worldwide since the end of 2019, emerging as an exceptional global crisis. This disorder was called "coronavirus disease 2019" or COVID-19. Clinical features are highly variable, and the clinical severity ranges from asymptomatic to fatal. The understanding of SARS-CoV-2 infection is ongoing. Several neurological symptoms were identified as part of the COVID-19 spectrum, including muscle pain, confusion, and headache ${ }^{[1]}$.

A study performed on 113 patients who deceased from COVID-19 revealed that acute respiratory distress syndrome with respiratory failure, sepsis, heart failure and subsequently hypoxic encephalopathy were the most common severe complications. The median age of the deceased patients was 68 years and male gender was predominant $(73 \%)$. Hypertension and other cardiovascular disorders were more frequent among the patients who died. Dyspnea, chest tightness and altered consciousness were more frequent in the deceased patients, as well as hyperCKemia (increased levels of creatine kinase, $\mathrm{CK})^{[2]}$.

Other retrospective studies provided partly similar results regarding CK, but data on this marker of muscle damage were only briefly mentioned in most papers, and a detailed literature review is not available to date. This exploratory literature review aimed to summarize early findings on the relevance of CK as a marker potentially associated with outcome in patients infected by Sars-CoV-2.

PubMed was searched up to May 13, 2020 for all articles about “(sars* OR covid* OR coronavirus) and (CK OR CPK OR creatine kinase OR creatine phosphokinase OR muscular OR muscle OR retrospective

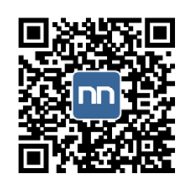


OR series)", and the abstracts were reviewed to identify all the relevant publications. The full text of all the retrospective case series or cohort studies which were identified according to this search were then screened for the following words: "kinase" or "CK" or "CPK". All the studies reporting data on CK levels (in any form) were included in this analysis and summarized in Table 1. Retrospective studies including only children or pregnant women were not considered. We mainly focused on the publications where there was a distinction between less severe and more severe cases (defined in any possible way, see Table 1) which could work as an outcome measure. These references, allowing an evaluation of CK as a marker potentially associated with outcome, are underscored in Table 1.

Twenty-one retrospective studies which included data on CK were identified [Table 1] $]^{[1-21]}$. Among these 21 papers, 12 (underscored in Table 1$)^{[2,4,6,7,9,10,14,15,18-21]}$ provided a measure of severity potentially useful to serve as an outcome measure. Eleven of these studies were from China and one from South Korea.

There is marked heterogeneity between these studies. In some instances, CK data were provided as a continuous variable, whereas other studies showed the fraction of patients with CK higher than a given value (different from study to study). In some cases, CK levels were presented as a mean, in others as a median. Furthermore, the definition of severe cases, and their percentage, mean (or median) age and gender proportion were also markedly different from study to study. Blood was sampled at admission in most of these retrospective studies (but not in all of them). These evident differences precluded further statistical analysis and a formal meta-analysis.

However, some conclusions could be drawn. In 11 of the 12 studies considered, CK levels were higher in the more severe group of COVID-19 patients ${ }^{[2,4,6,7,9,10,14,18-21]}$. Among these 11 studies, the difference reached statistical significance in 7 studies ${ }^{[2,7,14,18-21]}$, while there was no statistical significance in 4 . The significant studies included an average of 249 patients, compared with 69 patients in the other studies. Therefore, the lower power of the smaller studies could explain the fact that the difference did not reach statistical significance in some of these studies.

The five larger studies, each involving more than 160 patients, showed similar findings.

Chen and coworkers observed that CK levels at admission were markedly higher in the patients who subsequently died (median $189 \mathrm{U} / \mathrm{L}$ ) compared with the ones who recovered (median $84 \mathrm{U} / \mathrm{L})^{[2]}$.

Mao and coworkers reported that CK was higher in the patients with more severe pneumonia; unfortunately, this study did not explicitly specify when CK was tested ${ }^{[14]}$.

Zhang et al. ${ }^{[19]}$ reported that mean CK was higher in the patients with pneumonia compared with the patients with no radiological evidence of pneumonia; in the pneumonia group, higher CK could predict a more severe clinical picture.

Zheng et al. ${ }^{[20]}$ showed that median CK levels at admission were higher in the more severe group; hyperCKemia (>190 U/L) was present in $30 \%$ of the more severe cases $v s .6 \%$ of the others (significant difference).

Zhou et al. ${ }^{[21]}$ observed that median CK at admission was higher in the patients who subsequently died than in the subjects who were discharged; hyperCKemia (> 185 U/L) was observed in $21 \%$ of the deceased persons compared with $9 \%$ of the others, and was associated with death (univariate odds ratio $2.56,95 \%$ confidence interval 1.03-6.36). 
Table 1. Retrospective studies on COVID-19 including data on CK

\begin{tabular}{|c|c|c|c|c|c|c|c|c|}
\hline Author & Country & $\begin{array}{l}\text { Definition of } \\
\text { severe cases }\end{array}$ & $\begin{array}{l}\text { Severe/ } \\
\text { total } \\
\text { cases }\end{array}$ & $\begin{array}{l}\text { Mean age (or } \\
\text { median) }\end{array}$ & $\begin{array}{c}\text { Males } \\
(\%)\end{array}$ & $\begin{array}{l}\text { How CK is } \\
\text { reported }\end{array}$ & $\begin{array}{l}\text { When blood } \\
\text { was sampled }\end{array}$ & Results (concerning CK) \\
\hline Bhatraju et al. ${ }^{[3]}$ & $\begin{array}{l}\text { United } \\
\text { States }\end{array}$ & $\begin{array}{l}\text { Mechanical } \\
\text { ventilation }\end{array}$ & $18 / 24$ & 64 & $63 \%$ & $\begin{array}{l}\text { No. of cases } \\
\text { with } \mathrm{CKU} \\
100 \mathrm{U} / \mathrm{L}\end{array}$ & $\begin{array}{l}\text { During the } \\
\text { first } 3 \text { days in } \\
\text { ICU }\end{array}$ & $\begin{array}{l}\text { CK performed on only six ICU } \\
\text { patients (increased in three of } \\
\text { them) }\end{array}$ \\
\hline Chen et $a l^{[1]}$ & China & Death & $11 / 99$ & 56 & $68 \%$ & $\begin{array}{l}\% \text { of cases } \\
\text { with } C K> \\
310 \mathrm{U} / \mathrm{L}\end{array}$ & Admission & $\begin{array}{l}\text { Elevation of } \mathrm{CK} \text { in } 13(13 \%) \\
\text { patients, one of whom had CK } \\
6,280 \mathrm{U} / \mathrm{L}\end{array}$ \\
\hline Chen et al. ${ }^{[4]}$ & China & $\begin{array}{l}\text { More severe } \\
\text { respiratory } \\
\text { insufficiency }\end{array}$ & $11 / 21$ & 56 (median) & $81 \%$ & $\begin{array}{l}\text { Continuous } \\
\text { value }(U / L)\end{array}$ & Admission & $\begin{array}{l}\text { Median CK } 214 \mathrm{U} / \mathrm{L} \text { in severe cases } \\
\text { vs. } 64 \mathrm{U} / \mathrm{L} \text { in moderate cases (n.s.) }\end{array}$ \\
\hline Chen et $a l^{[2]}$ & China & Death & $\begin{array}{l}113 / \\
274\end{array}$ & 62 & $62 \%$ & $\begin{array}{l}\text { Continuous } \\
\text { value }(U / L)\end{array}$ & Admission & $\begin{array}{l}\text { CK was markedly higher in } \\
\text { deceased patients (median 189) } \\
\text { than in recovered ones (median } \\
\text { 84) (sign.) }\end{array}$ \\
\hline Chen et $a l^{[5]}$ & China & ? & $? / 78$ & 45 (median) & $50 \%$ & ? & $?$ & $\begin{array}{l}\text { ? (CK data cited in the results but } \\
\text { not shown in detail) }\end{array}$ \\
\hline Chen et $a l^{[6]}$ & China & Death & $19 / 55$ & 74 & $62 \%$ & $\begin{array}{l}\text { Continuous } \\
\text { value }(U / L)\end{array}$ & Admission & $\begin{array}{l}\text { Median CK } 213 \mathrm{U} / \mathrm{L} \text { in deceased } \\
\text { cases vs. } 106 \mathrm{U} / \mathrm{L} \text { in others (n.s.) }\end{array}$ \\
\hline Chen et al. ${ }^{[7]}$ & China & $\begin{array}{l}\text { More severe } \\
\text { respiratory } \\
\text { insufficiency }\end{array}$ & $43 / 145$ & 48 & $55 \%$ & $\begin{array}{l}\text { Continuous } \\
\text { value }(U / L)\end{array}$ & $?$ & $\begin{array}{l}\text { Severely ill patients had higher CK } \\
(90 \text { vs. } 60 \mathrm{U} / \mathrm{L}) \text { (sign.) }\end{array}$ \\
\hline Duet $a .^{[8]}$ & China & Death & $85 / 85$ & 66 (median) & $73 \%$ & $\begin{array}{l}\% \text { of cases } \\
\text { with } \mathrm{CK}> \\
170 \mathrm{U} / \mathrm{L}\end{array}$ & Admission & Increased CK in $37 \%$ \\
\hline Hong et al. ${ }^{[9]}$ & $\begin{array}{l}\text { South } \\
\text { Korea }\end{array}$ & ICU & $13 / 98$ & 55 & $39 \%$ & $\begin{array}{l}\text { continuous } \\
\text { value }(U / L)\end{array}$ & Admission & $\begin{array}{l}\text { Mean CK } 132 \text { in ICU patients and } \\
101 \text { in non-ICU (n.s.) }\end{array}$ \\
\hline Hou et al. ${ }^{[10]}$ & China & $\begin{array}{l}\text { "Clinically } \\
\text { advanced } \\
\text { pneumonia", } \\
\text { ICU, death }\end{array}$ & 17/101 & 51 (median) & $44 \%$ & $\begin{array}{l}\text { Continuous } \\
\text { value }(U / L)\end{array}$ & Admission & $\begin{array}{l}\text { CK higher in the more severe group } \\
\text { ( } 96 \text { vs. } 75 \mathrm{U} / \mathrm{L} \text { ) but not statistically } \\
\text { significant (n.s.) }\end{array}$ \\
\hline Huang et al..$^{[11]}$ & China & ICU & $8 / 34$ & 56 & $41 \%$ & ? & $?$ & $\begin{array}{l}\text { CK increased in one of the } 12 \\
\text { patients in whom it was tested }\end{array}$ \\
\hline Lescure et $a l^{[12]}$ & France & Death & $1 / 5$ & 46 (median) & $60 \%$ & $\begin{array}{l}\text { Continuous } \\
\text { value }(U / L)\end{array}$ & Admission & $\begin{array}{l}\text { Normal in } 4 \text { subjects; not tested in } \\
\text { the deceased patient }\end{array}$ \\
\hline Liu et al. ${ }^{[13]}$ & China & Death & $16 / 137$ & 55 & $45 \%$ & $?$ & $?$ & $\begin{array}{l}\text { ? (CK data not provided in the } \\
\text { results differently than declared in } \\
\text { the methods) }\end{array}$ \\
\hline Mao et al. ${ }^{[14]}$ & China & $\begin{array}{l}\text { More severe } \\
\text { pneumonia }\end{array}$ & $88 / 214$ & 53 & $41 \%$ & $\begin{array}{l}\text { Continuous } \\
\text { value }(U / L)\end{array}$ & $?$ & $\begin{array}{l}\text { Median CK higher in the severe } \\
\text { patients: } 83 \text { vs. } 59 \mathrm{U} / \mathrm{L} \text { (sign.) }\end{array}$ \\
\hline Mo et al. ${ }^{[15]}$ & China & $\begin{array}{l}\text { No remission } \\
\text { in } 10 \text { days } \\
\text { ("refractory") }\end{array}$ & $85 / 155$ & 54 (median) & $55 \%$ & $\begin{array}{l}\text { Continuous } \\
\text { value }(U / L)\end{array}$ & Admission & $\begin{array}{l}\text { Median CK } 89 \mathrm{U} / \mathrm{L} \text { in "refractory" } \\
\text { patients and } 100 \mathrm{U} / \mathrm{L} \text { in the other } \\
\text { patients (n.s.) }\end{array}$ \\
\hline Yang et al. ${ }^{[16]}$ & China & $?$ & $0 / 149$ & 45 & $54 \%$ & $\begin{array}{l}\% \text { of cases } \\
\text { with } \mathrm{CK}> \\
200 \mathrm{U} / \mathrm{L}\end{array}$ & Admission & CK increased in 12 cases ( $8 \%$ ) \\
\hline Zangrillo et al. ${ }^{[17]}$ & Italy & $\begin{array}{l}\text { Invasive } \\
\text { ventilation }\end{array}$ & $73 / 73$ & 61 (median) & $84 \%$ & $\begin{array}{l}\text { Continous } \\
\text { values }\end{array}$ & Admission & $\begin{array}{l}\text { Median (quartile 25\% - quartile } \\
75 \% \text { ) CK } 128 \text { U/L (101-471) }\end{array}$ \\
\hline Zhang et al. ${ }^{[18]}$ & China & $\begin{array}{l}\text { ICU/ } \\
\text { mechanical } \\
\text { ventilation or } \\
\text { death } \\
\text { ("composite } \\
\text { end-point") }\end{array}$ & $32 / 95$ & 49 (median) & $56 \%$ & $\begin{array}{l}\% \text { of cases } \\
\text { with CK } \\
<200 \\
\text { (normal) or } \\
200-400 \text { or } \\
400-600 \text { or } \\
>600 \mathrm{U} / \mathrm{L}\end{array}$ & $\begin{array}{l}\text { Highest } \\
\text { levels during } \\
\text { hospitaliza- } \\
\text { tion }\end{array}$ & $\begin{array}{l}\text { For }<200 \mathrm{U} / \mathrm{L} \text { group, } 17.9 \% \text { of the } \\
\text { patients reached the composite } \\
\text { endpoint. For } 200-400 \mathrm{U} / \mathrm{L} \text { group, } \\
41.7 \% \text { of the patients reached the } \\
\text { composite endpoint. For } 400-600 \\
\mathrm{U} / \mathrm{L} \text { group, } 44.4 \% \text { of the patients } \\
\text { reached the composite endpoint. } \\
\text { For }>600 \mathrm{U} / \mathrm{L} \text { group, } 57.1 \% \text { of the } \\
\text { patients reached the composite } \\
\text { endpoint. (sign.) } \\
\text { Higher CK activity correlated } \\
\text { strongly with severe pneumonia } \\
\text { and composite endpoint. (sign.) }\end{array}$ \\
\hline
\end{tabular}




\begin{tabular}{|c|c|c|c|c|c|c|c|c|}
\hline Zhang et $a{ }^{\left[{ }^{[19]}\right.}$ & China & $\begin{array}{l}\text { Radiological } \\
\text { evidence of } \\
\text { pneumonia }\end{array}$ & $\begin{array}{l}573 / \\
665\end{array}$ & $\begin{array}{l}47 \\
\text { (pneumonia) } \\
35 \text { (others) } \\
\text { (sign.) }\end{array}$ & $51 \%$ & $\begin{array}{l}\text { Continous } \\
\text { value }(\mathrm{U} / \mathrm{L})\end{array}$ & $?$ & $\begin{array}{l}\text { Mean CK } 73 \mathrm{U} / \mathrm{L} \text { (patients with } \\
\text { pneumonia) vs. } 63 \mathrm{U} / \mathrm{L} \text { (others) } \\
\text { (sign.) } \\
\text { In the pneumonia group, higher CK } \\
\text { could predict a more severe clinical } \\
\text { picture (univariate OR } 1.001 \text { with } \\
\text { confidence interval 1.000-1.002) } \\
\text { (sign.) }\end{array}$ \\
\hline Zheng et al. ${ }^{[20]}$ & China & $\begin{array}{l}\text { More severe } \\
\text { respiratory } \\
\text { insufficiency }\end{array}$ & $30 / 161$ & 45 (median) & $50 \%$ & $\begin{array}{l}\text { Both } \\
\text { continuous } \\
\text { values }(U / L) \\
\text { and \% of } \\
\text { cases with } \\
\text { CK }>190 \\
\text { U/L }\end{array}$ & Admission & $\begin{array}{l}\text { Median CK higher in severe } \\
\text { patients ( } 100 \text { vs. } 69 \mathrm{U} / \mathrm{L} \text { ) (sign.) } \\
\text { HyperCKemia present in } 30 \% \text { of } \\
\text { the more severe cases vs. } 6 \% \text { of } \\
\text { the others (sign.) }\end{array}$ \\
\hline Zhou et al. ${ }^{[21]}$ & China & Death & $54 / 191$ & 56 (median) & $62 \%$ & $\begin{array}{l}\text { Both } \\
\text { continuous } \\
\text { values (U/ } \\
\text { L) and \% of } \\
\text { cases with } \\
\text { CK }>185 \\
\text { U/L }\end{array}$ & Admission & $\begin{array}{l}\text { Median CK overall } 21.5 \mathrm{U} / \mathrm{L}: 39 \\
\mathrm{U} / \mathrm{L} \text { in the patients who died } \\
\text { and } 18 \mathrm{U} / \mathrm{L} \text { in subjects who were } \\
\text { discharged (sign.) } \\
\text { HyperCKemia }(>185 \mathrm{U} / \mathrm{L}): 22 / 168 \\
(13 \%) \text { overall: } 11 / 52(21 \%) \text { in } \\
\text { deceased subjects vs. } 11 / 116 \\
\text { (9\%) of the other patients (sign.). } \\
\text { HyperCKemia was associated with } \\
\text { death: univariate OR ( } 95 \% \mathrm{Cl}) 2.56 \\
(1.03-6.36) \text { (sign.) }\end{array}$ \\
\hline
\end{tabular}

?: data not provided in the given article; CK: creatine kinase; ICU: intensive care unit; n.S.: not significant difference; OR: odds ratio; Ref.: see reference list; Sign.: statistically significant difference

Taken together, the retrospective studies available to date (especially the larger ones) showed some association between CK levels and the clinical outcome of patients infected by SARS-CoV-2. CK was determined at hospital admission in most cases.

This preliminary review showed the limitations typical of all the systematic reviews based on retrospective studies. It is not possible to rule out the influence of various confounding factors in the original studies. Some of the included studies did not fully clarify inclusion criteria, course of disease and severity of disease. Lastly, most of these studies were performed in China, and this could lead to geographic and ethnicity biases.

Furthermore, data on CK levels were only briefly mentioned in most papers, and possible correlations with other clinical features (such as muscle pain) were not researched.

Only the retrospective study performed in Wuhan ${ }^{[14]}$ reported that "skeletal muscle injury" (defined in the following way: "when a patient had skeletal muscle pain and elevated serum CK", greater than $200 \mathrm{U} / \mathrm{L}$ ) was significantly more frequent in severe COVID-19, compared with less severe diseases (19\%vs. 5\%). Median CK levels were higher in the more severe group: 83 U/L (range 9-12,216) vs. 59 U/L (19-1,260). Interestingly, patients with "muscle injury" had multiorgan damage, including more severe liver and kidney abnormalities ${ }^{[14]}$.

Another Chinese retrospective work performed on compromised patients reported that muscle pain was an onset symptom in $22 \%{ }^{[2]}$. Interestingly, a European study performed on patients with much milder symptoms reported a higher prevalence of muscle pain $(63 \%)^{[22]}$.

Furthermore, severe rhabdomyolysis is a possible, rare complication of COVID-19 $9^{[23]}$.

A third of patients with other coronavirus infections (namely SARS) have manifested myalgia and elevated $\mathrm{CK}$, and in some instances rhabdomyolysis ${ }^{[24]}$. Therefore, even if electromyography (EMG), muscle imaging 
Table 2. Typical neurological features associated with mild and severe COVID-19

\begin{tabular}{ll}
\hline Neurological features typical of mild/initial cases & Neurological features typical of severe cases \\
\hline Headache & Delirium \\
Smell impairment & Impaired consciousness \\
Myalgia/muscle pain & Pyramidal signs \\
& Ischemic stroke (rare) \\
& Muscle damage with increased CK \\
\hline
\end{tabular}

CK: creatine kinase

or muscle histopathology is not available to date, coronavirus infections may possibly cause viral myositis on the basis of the above reported data ${ }^{[24]}$. Immune-mediated mechanisms should also be considered ${ }^{[25]}$. Furthermore, severely ill patients may develop weakness due to muscle atrophy from disuse and/or critical illness myopathy (and/or polyneuropathy), so specifically designed studies are needed ${ }^{[24]}$.

The most common neurological features associated with COVID-19 are presented in Table 2. Muscle pain is common in both mild and severe cases, and in the most compromised patients, it is accompanied by increased CK levels and possibly true myopathic damage.

Interestingly, angiotensin converting enzyme 2, which was identified as the functional receptor for SARS$\mathrm{CoV}-2$, is present in multiple human tissues, including skeletal muscle and nervous system ${ }^{[14]}$. Therefore, the longitudinal follow-up of people who have been infected by SARS-CoV-2 should include a careful assessment of the neuromuscular system. There is a strong need for prospective and specifically designed studies, including EMG, muscle imaging, muscle histopathology and PCR assay for detection of SARS$\mathrm{CoV}-2$ in muscle tissue.

In conclusion, some association between CK levels and the clinical outcome of patients infected by SARSCov-2 seems to exist, but the precise mechanisms are still unknown. The influence of this novel coronavirus on voluntary muscle really needs to be clarified.

\section{DECLARATIONS}

\section{Authors' contributions}

The author contributed solely to this article.

\section{Availability of data and materials}

Not applicable.

\section{Financial support and sponsorship}

None.

\section{Conflicts of interest}

The author declared that there are no conflicts of interest.

\section{Ethical approval and consent to participate}

Not applicable.

\section{Consent for publication}

This Ediotrial can be published in the present form.

\section{Copyright}

(c) The Author(s) 2021. 


\section{REFERENCES}

1. Chen N, Zhou M, Dong X, et al. Epidemiological and clinical characteristics of 99 cases of 2019 novel coronavirus pneumonia in Wuhan, China: a descriptive study. Lancet 2020;395:507-13.

2. Chen T, Wu D, Chen H, et al. Clinical characteristics of 113 deceased patients with coronavirus disease 2019: retrospective study. $B M J$ 2020;368:m1091.

3. Bhatraju PK, Ghassemieh BJ, Nichols M, et al. Covid-19 in critically ill patients in the seattle region - case series. $N$ Engl J Med 2020;382:2012-22.

4. Chen G, Wu D, Guo W, et al. Clinical and immunological features of severe and moderate coronavirus disease 2019. J Clin Invest 2020;130:2620-9.

5. Chen X, Yang Y, Huang M, et al. Differences between COVID-19 and suspected then confirmed SARS-CoV-2-negative pneumonia: a retrospective study from a single center. J Med Virol 2020; doi: 10.1002/jmv.25810.

6. Chen T, Dai Z, Mo P, et al. Clinical characteristics and outcomes of older patients with coronavirus disease 2019 (COVID-19) in Wuhan, China (2019): a single-centered, retrospective study. J Gerontol A Biol Sci Med Sci 2020; doi: 10.1093/gerona/glaa089.

7. Chen Q, Zheng Z, Zhang C, et al. Clinical characteristics of 145 patients with corona virus disease 2019 (COVID-19) in Taizhou, Zhejiang, China. Infection 2020;48:543-51.

8. Du Y, Tu L, Zhu P, et al. Clinical features of 85 fatal cases of COVID-19 from wuhan: a retrospective observational study. Am J Respir Crit Care Med 2020;201:1372-9.

9. Hong KS, Lee KH, Chung JH, et al. Clinical features and outcomes of 98 patients hospitalized with SARS-CoV-2 infection in daegu, south korea: a brief descriptive study. Yonsei Med J 2020;61:431-7.

10. Hou W, Zhang W, Jin R, et al. Risk factors for disease progression in hospitalized patients with COVID-19: a retrospective cohort study. Infect Dis (Lond) 2020;52:498-505.

11. Huang Y, Tu M, Wang S, et al. Clinical characteristics of laboratory confirmed positive cases of SARS-CoV-2 infection in Wuhan, China: a retrospective single center analysis. Travel Med Infect Dis 2020;101606.

12. Lescure FX, Bouadma L, Nguyen D, et al. Clinical and virological data of the first cases of COVID-19 in Europe: a case series. Lancet Infect Dis 2020;20:697-706.

13. Liu K, Fang YY, Deng Y, et al. Clinical characteristics of novel coronavirus cases in tertiary hospitals in Hubei Province. Chin Med J (Engl) 2020;133:1025-31.

14. Mao L, Jin H, Wang M, et al. Neurologic manifestations of hospitalized patients with coronavirus disease 2019 in wuhan, china. JAMA Neurol 2020;77:683-90.

15. Mo P, Xing Y, Xiao Y, et al. Clinical characteristics of refractory COVID-19 pneumonia in Wuhan, China. Clin Infect Dis 2020; doi: $10.1093 /$ cid/ciaa270.

16. Yang W, Cao Q, Qin L, et al. Clinical characteristics and imaging manifestations of the 2019 novel coronavirus disease (COVID-19): a multi-center study in Wenzhou city, Zhejiang, China. J Infect 2020;80:388-93.

17. Zangrillo A, Beretta L, Scandroglio AM, et al. Characteristics, treatment, outcomes and cause of death of invasively ventilated patients with COVID-19 ARDS in Milan, Italy. Crit Care Resusc 2020.

18. Zhang G, Zhang J, Wang B, et al. Analysis of clinical characteristics and laboratory findings of 95 cases of 2019 novel coronavirus pneumonia in Wuhan, China: a retrospective analysis. Respir Res 2020;21:74.

19. Zhang X, Cai H, Hu J, et al. Epidemiological, clinical characteristics of cases of SARS-CoV-2 infection with abnormal imaging findings. Int J Infect Dis 2020;94:81-7.

20. Zheng F, Tang W, Li H, et al. Clinical characteristics of 161 cases of corona virus disease 2019 (COVID-19) in Changsha. Eur Rev Med Pharmacol Sci 2020;24:3404-10.

21. Zhou F, Yu T, Du R, et al. Clinical course and risk factors for mortality of adult inpatients with COVID-19 in Wuhan, China: a retrospective cohort study. Lancet 2020;395:1054-62.

22. Lechien JR, Chiesa-Estomba CM, Place S, et al. Clinical and epidemiological characteristics of 1,420 european patients with mild-tomoderate coronavirus disease 2019. J Intern Med 2020;288:335-44.

23. Jin M, Tong Q. Rhabdomyolysis as potential late complication associated with COVID-19. Emerg Infect Dis 2020;26:1618-20.

24. Guidon AC, Amato AA. COVID-19 and neuromuscular disorders. Neurology 2020;94:959-69.

25. Leung TW, Wong KS, Hui AC, et al. Myopathic changes associated with severe acute respiratory syndrome: a postmortem case series. Arch Neurol 2005;62:1113-7. 